\title{
Når forberedelse er en pligt, og undervisningen er et privilegium: et casestudie af universitetsstude- rendes forberedelsespraksis
}

Kim J. Herrmann, lektor, ph.d., Center for Undervisning og Læring, Aarhus Universitet

Anna Bager-Elsborg, ph.d., postdoc, Center for Undervisning og Læring, Aarhus Universitet

Videnskabelig artikel, fagfællebedømt

Kvantitative tværsnitsundersøgelser har de senere år kortlagt omfanget af danske universitetsstuderendes forberedelse, hvorimod der kun i beskedent omfang er forsket $i$, hvorfor og under hvilke omstændigheder studerende forbereder sig lidt eller meget. Med afsæt i praksisteori analyserede vi gruppeinterview med studerende fra et bachelorfag, hvor studerende kun kunne møde op til undervisningen, hvis de var forberedte (forberedelsespligt). Analysen viste, at de studerende var imod forberedelsespligt generelt, men til gengæld accepterede forberedelsespligten i det pågældende fag. Derfor analyseredes de omstændigheder, under hvilken de studerende accepterede forberedelsespligten. Studiet bidrager til den eksisterende viden om universitetsstuderendes forberedelse ved at undersøge forberedelse som en praksis, som ikke alene vedrører individuelle studerendes adfærd, men ligeledes omhandler uudtalte normer, undervisningens organisering og karakteren af relationerne studerende og underviser imellem. Studiet peger på, at forberedelsespligt ikke nødvendigvis står i modsætningsforhold til universitetets kerneværdier, men tværtimod kan komplementere værdier som frihed, mulighed og selvstændighed.

\section{Introduktion}

På universitetet udgør selvstudium og forberedelse forud for undervisningstimerne en vigtig del af de studerende studiepraksis, og interessen for, hvor meget danske universitetsstuderende forbereder sig, har gennem de seneste 10 år været voksende. En række tværsnitsstudier har unders $\varnothing \mathrm{gt}$, hvor mange timer universitetsstuderende bruger på deres studier (DEA, 2013; Herrmann, Bager-Elsborg, Hansen, \& Nielsen, 2015; Kvalitetsudvalget, 2014; Orr, Gwosc, \& Netz, 2011; Aarhus Universitet, 2011, 2014), og et udsnit af disse undersøgelser har også påvist en betydelig spredning i antallet af timer, studerende bruger på at forberede sig (Herrmann et al., 2015; Kvalitetsudvalget, 2014). I Kvalitetsudvalgets (2014) undersøgelse svarede 27 procent af de adspurgte studerende, at de ofte eller meget ofte $m \varnothing d e r$ uforberedt op til undervisningen.

Mens de ovennævnte studier har fokuseret på at beskrive omfanget af danske universitetsstuderendes forberedelsesindsats, har kun et fåtal prøvet at forklare og forstå, hvorfor nogle studerende forbereder sig meget, mens andre forbereder sig lidt, og hvorfor studerende forbereder sig meget til nogle undervisningsforløb, men forbereder sig mindre til andre. Et tværsnitsstudie af Herrmann et al. (2015) fandt, at antallet af undervisningstimer kun i meget begrænset omfang forklarer antallet af forberedelsestimer. På baggrund af analyserne foreslog forfatterne, at det er organiseringen af undervisningstimerne snarere end antallet af undervisningstimer i sig selv, som påvirker studerendes forberedelse, uden at forfatterne dog kunne præsentere yderligere belæg for en sådan påstand. Kvalitetsudvalget $(2014$, p. 56) har påvist en korrelation mellem omfanget 
af forberedelse og graden af opmærksomhed på de studerendes forberedelse fra uddannelsesinstitutionens side, uden at forfatterne har kunnet forklare en sådan korrelation nærmere.

Dette studie bidrager til den eksisterende viden om danske universitetsstuderendes forberedelsesindsats ved kvalitativt at belyse, hvordan forberedelse opleves i en studiepraksis. Gennem et kvalitativt casestudie bliver det muligt i højere grad at forstå og forklare, hvorfor der ikke er en stærkere sammenhæng mellem antallet af undervisningstimer og antallet af forberedelsestimer. Med afsæt i praksisteori analyseres et specifikt undervisningsforl $\varnothing b$, hvor der var forberedelsespligt, hvilket vil sige, at de studerende ikke kunne møde op, medmindre de var forberedt. Først beskrives artiklens teoretiske udgangspunkt. Dernæst fremlægges undersøgelsens design, en beskrivelse af den valgte case samt de metodiske valg. Efterfølgende afrapporteres unders $\varnothing$ gelsens resultater $i$ artiklens analyseafsnit. Afslutningsvis diskuteres resultaterne.

\section{Forberedelse og undervisning som en praksis}

For at forstå, hvordan normer om forberedelse etableres og opretholdes, hjælper det at anskue undervisning som en praksis indlejret $\mathrm{i}$ andre praksisser. En praksis er konstitueret af både handlinger, udsagn, sagte og usagte regler, der skaber et rum for passende adfærd, og hvor upassende eller uacceptable handlinger sanktioneres socialt (Reckwitz, 2002). Universitetet eller det akademiske fællesskab udgør en praksis, men også en uddannelse udgør en praksis, ligesom det enkelte undervisningsforløb eller holdforløb udgør en praksis. Der opstår et fællesskab, hvor én adfærd er mere almindelig eller socialt accepteret end en anden. Disse normer for passende adfærd er ofte uudtalte og bliver med tiden tavs viden for dem, der er del af praksissen. Sammenfattende kan man benævne en praksis, der sætter rammerne for passende adfærd, et teaching and learning regime (Trowler, 2008; Trowler \& Cooper, 2002), og det kan dekomponeres i otte konstituerende elementer: 1) eksisterende praksisser, 2) tavse antagelser om passende adfærd, 3) implicitte teorier om studerende, undervisning og læring, 4) diskursive repertoirer, 5) konventioner om passende og upassende adfærd i undervisningssammenhæng, 6) magtrelationer, 7) identitet eller konstruktionen af selvet i relation til andre, og endelig 8) tilskrivning af mening og følelser til ideer, praksisser og institutioner (Trowler, 2008, 55). Disse otte komponenter er ikke gensidigt udelukkende, men bidrager til at vise kompleksiteten i en praksis, og undervisning og adfærden omkring undervisning, studieadfærd og forberedelse er kontinuerligt forhandlede fortolkninger af det dominerende teaching and learning regime og de dominerende normer for passende adfærd. Trowler argumenterer for, at vores handlinger med tiden bliver til vaner. De bliver uovervejede og svære at ændre, fordi den eksisterende praksis internaliseres som det mest naturlige i verden (Trowler, 2008, p. 69). Praksissers indhold og betydning bliver særligt tydelig, når der sker et brud med vaner of rutiner. Et sådant brud kaster lys på antagelser i relationerne mellem deltagerne, forventninger til de studerendes roller, og hvad der opleves som passende adfærd. Dette illustrerede Trowler i et studie af universitetssammenlægninger i Sydafrika, hvor nye rutiner, relationer og identiteter måtte forhandles, fordi de eksisterende praksisser kolliderede (Trowler, 2008, p. 86, 100).

For at analysere den specifikke undervisningspraksis og forstå, om forberedelsespligt kan etableres som en acceptabel del af en given undervisningspraksis, valgte vi at undersøge dele af et konkret teaching and learning regime. Dette teaching and learning regime afspejlede en praksis, der brød med normalen om frihed til at planlægge egne studierutiner ved at indføre en pligt til forberedelse. For at udforske, hvad bruddet med de eksisterende normer afslørede om både 
eksisterende og nye praksisser, udvalgte vi tre analytiske parametre af et teaching and learning regime. Det første var at undersøge den nye praksis i sammenligning med 'plejer'. Et brud med 'plejer' giver mulighed for at opdage og udfordre normalen, og derfor sammenlignes undervisning med forberedelsespligt med undervisning uden.

Den anden komponent var magtrelationerne i undervisningen. Magtrelationer er den sjette af de otte komponenter nævnt ovenfor. Der er altid magt på spil i undervisning blot ved det, at underviseren kan definere, hvad der skal foregå i undervisningen, hvad de studerende skal lave uden for undervisningen, og hvordan deres præstationer skal bedømmes. Endvidere er der magt $\mathrm{i}$ relationerne mellem de studerende, hvor det forhandles, hvem der er toneangivende, og hvem der sanktionerer passende og upassende adfærd. På den måde kan magten være både direkte og indirekte (Trowler, 2008, p. 98-99). Magtrelationerne er på den ene side givet af de hidtidige praksisser, men samtidig kan de undergå forandring, når der etableres nye regler.

Den tredje og sidste komponent var de studerendes konstruktion af sig selv i rollen som studerende (som vi i analysen blot omtaler 'identiteten som studerende'). Trowler argumenterer for, at interaktionerne mellem individer automatisk medfører en forhandling af identitetsposition (Trowler, 2008, p. 102). At undersøge studerendes konstruktioner af sig selv i rollen som studerende er et logisk næste skridt efter at have unders $\emptyset$ gt bruddet med den normale forberedelsespraksis og magtrelationerne $\mathrm{i}$ undervisningen. Forandrede praksisser og nye måder at være sammen i undervisningslokalet på har potentiale til at tilbyde de studerende nye roller, men også til at udfordre eksisterende roller. Det rejste spørgsmålet, hvilken rolle den studerende kunne indtage og fik tilbudt i det givne undervisningsforløb.

\section{Forskningsspørgsmål}

I dette studie undersøger vi universitetsstuderendes forberedelsespraksis ved hjælp af et undervisningsforl $\emptyset b$, som brød med normal praksis, idet der i dette forl øb var indført forberedelsespligt. Vi stillede derfor følgende spørgsmål:

1. Accepterer universitetsstuderende forberedelsespligt?

2. Hvad henholdsvis fremmer og hindrer studerendes accept af forberedelsespligt?

Når studiet her særligt interesserer sig for forberedelsespligten, skyldes det, at den var et brud med den hidtidige praksis og dermed var anledning til at undersøge nogle af de hidtidige vaner og rutiner.

\section{Metode}

\section{Casen og casedesignet}

De universitetsstuderendes forberedelsespraksisser blev unders $\varnothing$ gt $\mathrm{i}$ et specifikt undervisningsforløb, som udgør studiets case. Yin (2012, p. 4) definerer et casestudie som 'an empirical inquiry about a contemporary phenomenon (e.g., a case), set within its real-world context'. Af særligt to grunde er casestudiet velegnet til at belyse de præsenterede forskningsspørgsmål. For det første er casestudiet velegnet, når målet er at forstå meningskonstruktion i dybden - specielt når grænsen mellem det fænomen, man ønsker at undersøge (i dette tilfælde forberedelsespraksis), og konteksten ikke er klart afgrænsede (Gerring, 2008, p. 37; Yin, 2012). For det andet giver casestudiedesignet mulighed for at undersøge den normale praksis over for den afvigende praksis 
(Gerring, 2008, p. 106). Ved at vælge en afvigende case (et undervisningsforløb med forberedelsespligt) belyses også undervisningsforløb uden forberedelsespligt.

Det undersøgte undervisningsforløb var et bachelorprojektseminar, som i efteråret 2015 med deltagelse af 31 studerende blev afholdt på en humanistisk uddannelse på et større dansk universitet. Forløbet var normeret til 15 ECTS-point. Seminaret blev afsluttet med en skriftlig bacheloropgave, som blev karakterbed $\varnothing \mathrm{mt}$ med ekstern censur. Tolv gange i løbet af semesteret var der holdtimer af tre timers varighed. Undervisningen blev varetaget af en lektor med mange års undervisningserfaring. Modsat hvad der er normalt for undervisningsforløb på pågældende uddannelse, var deltagelse i undervisningen frivillig. Forud for hver undervisningsgang skulle de studerende løse og aflevere en skriftlig opgave af 1-5 siders omfang relevant for deres individuelle projekt. Disse afleveringer var omdrejningspunktet for den efterfølgende holdundervisning, som typisk vekslede mellem gruppearbejde, plenumdiskussioner, peer-feedback og enkelte underviseroplæg.

Det kendetegnende og teoretisk interessante ved den valgte case var forberedelsespligten. Det følgende er et tekstuddrag fra en mail sendt fra underviseren til de studerende forud for undervisningen:

Som varslet før sommerferien kommer her en opgave, som skal være udført til første gang, vi mødes, således at vi har noget at tale om. (...) Undervisningen er frivillig (...), til gengæld kan man kun komme til undervisningen, hvis man har afleveret ugens opgave. De seneste seks års forløb viser, at der er klart større odds for at lave et godt projekt til tiden, hvis man har fulgt forløbet. Og at der er klart større odds for at lave et godt projekt, hvis man tager imod den vejledning og peer-feedback, som forløbet iscenesætter. (Uddrag af mail fra underviser)

Forberedelsen var som hovedregel skriftlig. Der var forberedelse til hver undervisningsgang. Det skriftlige materiale skulle altid følges af en skrivelse, hvori de studerende forholdt sig til, hvilken status teksten havde, og hvad de gerne ville have feedback på.

\section{Dataindsamling}

Der blev gennemført to gruppeinterviews med deltagelse af tre studerende per interview. Gruppeinterview har fordele, når man undersøger forhandlede meninger (Barbour \& Kitzinger, 1998), da individuelle udsagn $\mathrm{i}$ interviewsituationen enten kan bekræftes eller modsiges af de andre studerende. I denne kontekst var vi interesserede i de studerendes oplevelse af normal forberedelsespraksis sammenlignet med deres praksis i bachelorfaget. De studerendes viden omkring undervisning og forberedelse er såkaldt implicit viden, og det at lade de studerende diskutere deres forberedelse med hinanden gav de studerende mulighed for at reflektere over deres egen praksis (Flick, 2014). Interviewene var semistrukturerede, hvilket gav mulighed for på den ene side at styre samtalen i forhold til de teoretisk relevante temaer, men samtidig gjorde det muligt, at samtalen kunne udvikle sig i den retning, der var mest interessant. Interviewguiden dækkede emner såsom motivation, praktisk organisering af faget samt forventninger til andre studerendes og egen adfærd. Et af spørgsmålene stillet i gruppeinterviewene var: "Hvis I nu prøver at tænke tilbage, hvad plejede der så at ske, når I mødte op til undervisning?" eller: "Kan I fortælle noget 
om, hvordan I typisk forberedte jer inden undervisningen? Var der nogle gange, hvor I ikke var forberedt?"

De studerende blev oplyst om, at deres udsagn ville blive anonymiseret. Interviewene varede henholdsvis 59 og 45 minutter, og de transskriberede interview havde et omfang af knap 50 normalsider. Interviewene er tilgængelige efter særlig aftale med forfatterne. 


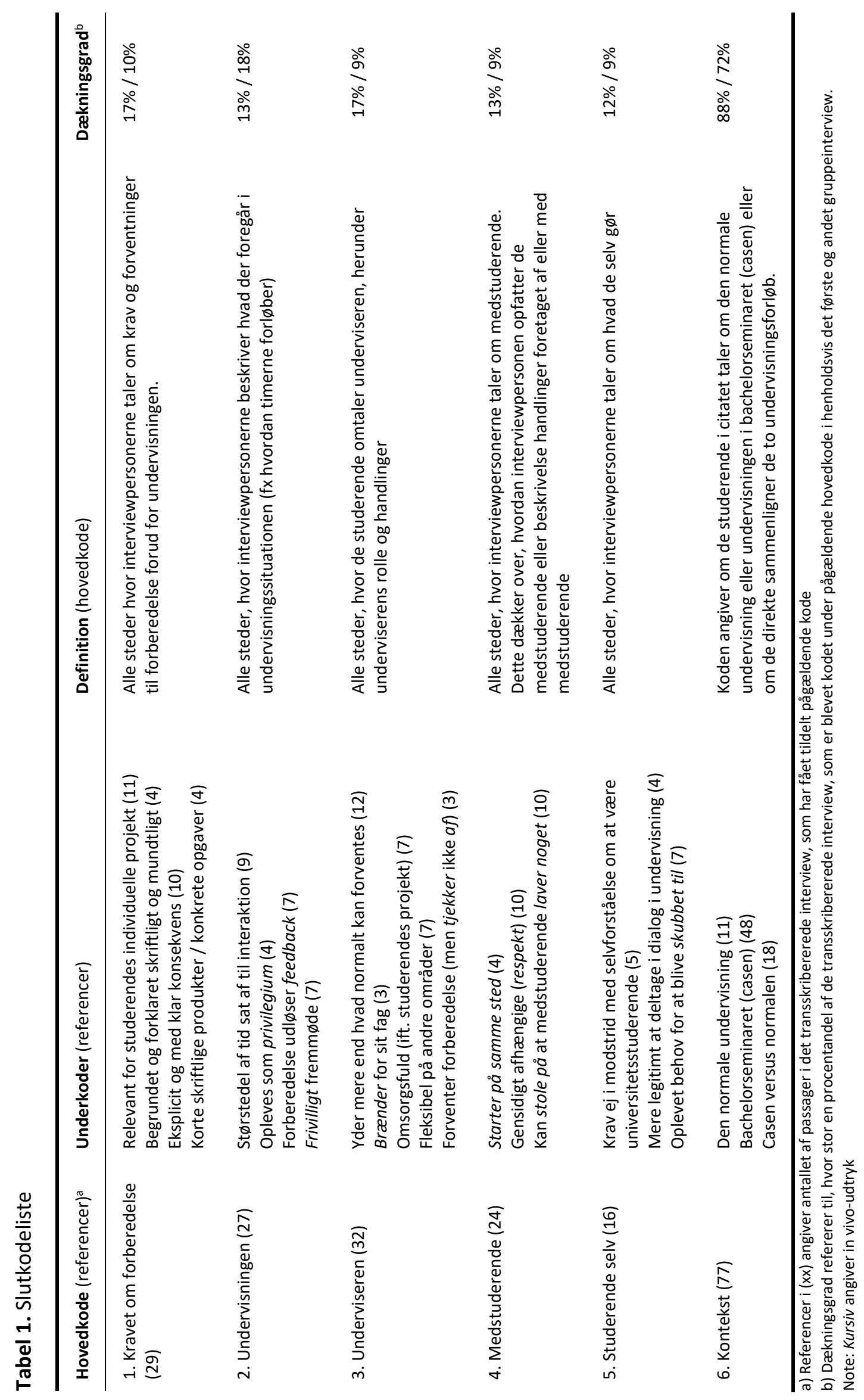




\section{Kodning og analysestrategi}

Indledende blev de transskriberede interview læst igennem, og der blev foretaget en første åben og induktiv kodning, hvor der blev dannet fem hovedkoder, som udgjorde overordnede temaer $\mathrm{i}$ interviewene: (1) 'kravet om forberedelse', (2) 'undervisningen', (3) 'underviseren', (4) 'medstuderende', (5) 'studerende selv'. Der blev herefter foretaget en ny åben og induktiv kodning inden for hvert af de fem hovedområder. Dette resulterede i en slutkodeliste bestående af 6 hovedkoder og 23 underkoder (se tabel 1). På baggrund af slutkodelisten blev der foretaget en lukket kodning af hele datamaterialet. Kodning blev foretaget i NVivo 11.

Selv om koderne er dannet induktivt, relaterer de stadig til de valgte praksisteoretiske parametre, som er beskrevet ovenfor. Hovedkode 1 og 2 korresponderer med det teoretiske parameter 'forberedelsespraksis', hovedkode 3 og 4 korresponderer med det teoretiske parameter 'magtrelationer', og hovedkode 5 korresponderer med det teoretiske parameter 'identiteten som studerende' (se figur 1).

Analysen fulgte to metodiske principper, som er beskrevet i Miles og Huberman (1994). Det første princip handler om at analyse kvalitative data ved at sammenligne og modstille data (eng. compare and contrast). Denne metode er hensigtsmæssig i dette studie, da studiet sigter mod at afdække uudtalte normer i den normale praksis ved at interviewe studerende, der har oplevet et undervisningsforl $\emptyset \mathrm{b}$, som afviger fra normal praksis. Vi analyserede således interviewene ved hele tiden at sammenligne og modstille de studerende udsagn om henholdsvis normalens og casens undervisningsforløb inden for hvert tema. Det andet princip handler om at vise data (eng. display) for at dokumentere resultater. Vi har valgt at vise data i figur 1 og ved at vise citater, som underbygger analytiske fund.

\section{Analyse}

Beskrivelsen af analysen falder $\mathrm{i}$ tre dele, som følger de af praksisteorien afledte tre teoretiske parametre: forberedelsespraksis, magtrelationer og identitet som studerende. 


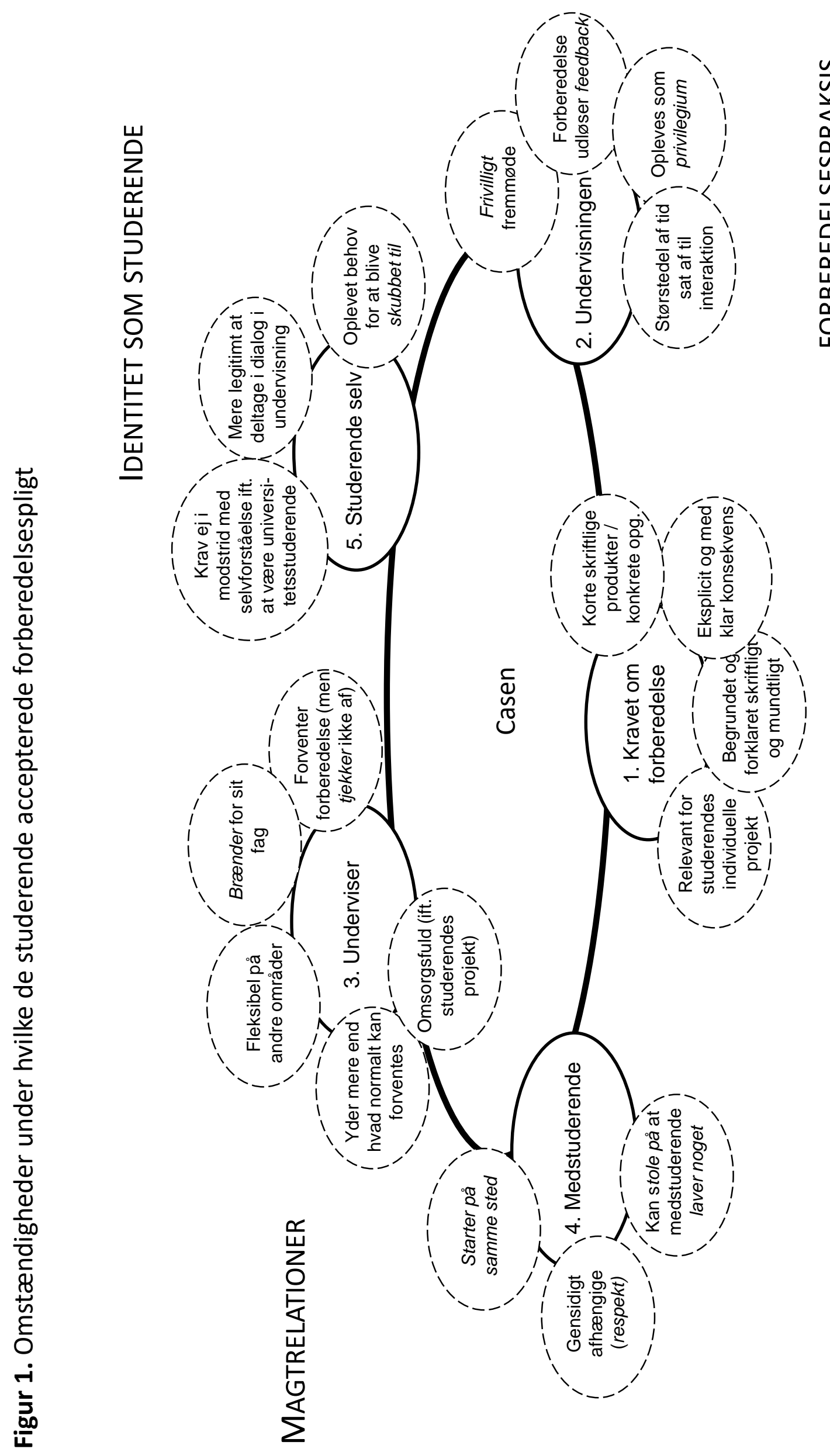

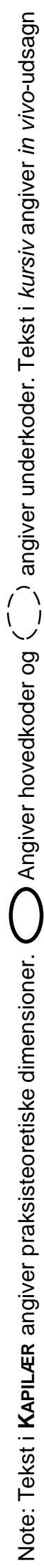




\section{Forberedelsespraksis}

Analysens første del søgte at besvare, hvordan de studerende oplevede et undervisningsforløb, hvor der var forberedelsespligt, og således adresseres forskningsspørgsmålet om, hvorvidt universitetsstuderende accepterer forberedelsespligt. Forberedelsespligten som fænomen er interessant, særligt fordi det var et krav, der adskilte sig fra normalen i den undervisning, de studerende hidtil havde mødt på universitetet. I det følgende vises, hvordan den normale forberedelsespraksis adskiller sig fra den i casen. Herefter belyses, hvordan de studerende ud fra en generel betragtning var afvisende over for forberedelsespligt, mens de - modsat - i det givne undervisningsforløb accepterede forberedelsespligten som værende legitim.

De studerende beskrev, hvordan undervisning, som de tidligere havde oplevet det, typisk bestod af forelæsning på mindre eller større hold. Deres forberedelse bestod sædvanligvis i at læse tekster, som underviseren efterfølgende forelæste over.

I tidligere undervisningsforløb, der har det været sådan, at vi har haft nogle tekster til den her gang, og så skulle vi læse dem. Men ja, der skete jo ikke noget, hvis man ikke havde læst det. Altså, der var ikke nogen konsekvenser. (Mandlig studerende)

Hvis det var en forelæser, som ligesom står i tre timer, så virker det fjollet, at man har fået krav på [er blevet afkrævet] at læse det hele, fordi man ikke bruger det. (Mandlig studerende)

Citaterne viser, at de studerende havde været vant til undervisning, hvor der var krav om forberedelse formelt set, men at det i praksis var helt op til de studerende selv. Forberedelsen blev opfattet som en mulighed, men ikke en nødvendig forudsætning for at deltage i undervisningen. For de studerende kunne det være meningsfuldt at undlade at forberede sig. Fx hvis underviseren ikke behandlede det, den studerende fandt svært. I det tilfælde blev forberedelsen opfattet som spildt.

De studerende blev spurgt, om forberedelsespligten fra casen efter deres mening kunne overføres til andre fag, men dette afviste de studerende samstemmende. At stille krav om obligatorisk forberedelse til undervisning blev opfattet som kontrol.

Jeg kan huske, at min gymnasielærer altid gjorde det og sagde: "Hvis ikke I har læst det her, eller hvis ikke I har lavet de her opgaver, så må I ikke være med", og så skulle vi gå uden for døren. Så synes jeg bare, vi går ned på et eller andet ... Jeg kan godt følge princippet. Jeg tror bare ikke, at jeg ville være fortaler for det i almindelige situationer. Så minder det mig bare for meget om min gymnasielærer. (Kvindelig studerende)

Et krav om forberedelse blev oplevet som hørende til gymnasiet og som en fratagelse af ansvaret for og friheden til at tilrettelægge egen studiehverdag.

Hvor et princip om forberedelsespligt blev afvist på det generelle plan, blev det til gengæld accepteret i det undervisningsforløb, som udgjorde casen. I modsætning til den normale eller klassiske undervisning oplevede de studerende, at forberedelsespligten var så tydeligt italesat, at det var uacceptabelt at møde uforberedt op.

Der var sat nogle rammer op omkring det. Selvom det var frivilligt [at komme til undervisningen], så måtte vi ikke deltage, medmindre vi havde lavet delafleveringer eller forberedt os. Så man ligesom kunne vide, at vi kom forberedte. Ellers blev vi faktisk bedt om 
ikke at møde op. Jeg tror ikke, der var mange der tog chancen og kom ellers. Det var ikke sådan, hvor man bare lige sådan mødte op og hyggede. Det virkede mere seriøst, synes jeg, end mange af de andre undervisningsgange vi havde. (Mandlig studerende)

Ud over den klare italesættelse af forberedelsespligten var undervisningen organiseret, så det var $n \varnothing d v e n d i g t$ at være forberedt for at kunne deltage i aktiviteterne i timerne. Den studerende beskriver undervisningen som 'seriøs' i modsætning til undervisning, hvor man kan møde uforberedt op og 'hygge'.

De studerende beskrev, at de havde forberedt sig meget gennem hele semestret for at kunne deltage i undervisningen. Det blev oplevet som pinligt ikke at være forberedt, og da der ikke var fremmødepligt, kunne uforberedte studerende blive hjemme. På denne måde blev undervisningen oplevet som et tilbud - sågar et privilegium - for dem, der havde materiale, de gerne ville have feedback på.

Og det var ikke bare, fordi vi havde læst en tekst, og så skulle vi sætte os ned på vores plads og så høre på hende [underviser] snakke i tre timer. (Mandlig studerende)

Det var merer sådan, at fordi vi havde forberedt os, så havde vi en række privilegier, som vi kunne bruge og få adgang til. (Mandlig studerende)

De studerende oplevede, at deres forberedelse var relateret til deres deltagelse i undervisningen og ikke blot et bagtæppe for at høre underviseren tale. På trods af, at de studerende også beskrev, at det var hårdt arbejde, og at de nogle gange skulle arbejde mere end andre studerende, de kendte, oplevede de tilsvarende, at det var meningsfuldt. En studerende beskrev det således:

Vi skal lave noget mere sådan rent formelt, men vi har ligesom nogle goder ved at aflevere. (Mandlig studerende)

Opsummerende kan man sige, at forberedelsespligten var tydeligt italesat og blev opfattet som legitim af de studerende. Forskellen mellem den tydelige italesættelse i denne kontekst sammenlignet med gymnasiekonteksten var fraværet af kontrol (se næste afsnit). Pligten var ikke formynderisk, men meningsfuld, fordi den relaterede direkte til deres arbejde med bacheloropgaven. Dertil beskrev de undervisningen som et privilegium, som de fik adgang til, når de havde forberedt sig.

\section{Magtrelationer}

I dette afsnit afrapporteres analysen af det andet teoretiske parameter, nemlig magtrelationerne. Det gør vi ved først at analysere relationerne de studerende imellem og dernæst analysere relationen mellem underviser og studerende.

Fordi peer-feedback var en bærende aktivitet, var undervisningen helt afhængig af, at de studerende var forberedte på deres eget materiale og var villige til at give feedback på deres medstuderendes arbejde. Forberedelsespligten var medvirkende til, at de studerende kunne 'stole på', at medstuderende 'lavede noget', og dermed stole på, at kvaliteten af medstuderendes feedback $\operatorname{var} h \varnothing j$ :

Jeg fik altid en god form for feedback. Jeg kunne også stole på mine medstuderende - at de lavede noget, at der var noget arbejde i det, de sagde. Der var næsten ikke mulighed for, at der var nogen, der ikke gad, for de måtte ikke komme. Derfor var det sådan tovejs (...). Og [underviser] sagde, at det var ikke okay at komme, hvis ikke man havde lavet no- 
get. Så på den måde var det bare sådan, at det blev en eller anden form for feedback, som var, som kunne bruges til noget. (Mandlig studerende)

Peer-feedback gjorde de studerende gensidigt afhængige, og på grund af forberedelsespligten blev denne gensidige afhængighed oplevet positivt af de interviewede studerende.

De studerende beskrev feedback i denne situation som en modsætning til tidligere oplevelser, hvor de enten ikke turde dele deres arbejde med andre studerende, eller oplevelser, hvor feedback fra medstuderende havde været abstrakt og uanvendelig. Her bidrog den obligatoriske forberedelse til at sætte en standard for, hvornår man som studerende legitimt kunne deltage $\mathrm{i}$ undervisningen. Forberedelsespligten sikrede også, at de studerende oplevede 'at starte samme sted', hvilket illustreres i citatet:

Jeg tror også, at det der med obligatorisk forberedelse, det er en supergod nedre grænse for, hvad der er dumme spørgsmål. Fordi man vidste, at hvis man havde forberedt sig, og hvis man dukkede op, når man så møder op, så er der ikke noget der hedder dumme spørgsmål, fordi vi ligesom alle sammen har lavet det minimum. Og så, altså, så kan man ligesom spørge om alt, og det er okay. (Mandlig studerende)

At de studerende oplevede, at der ikke var 'dumme spørgsmål', var også afgjort af, at de kunne være sikre på, at deres medstuderende var forberedte, og at der dermed var et fælles udgangspunkt for undervisningen. På den måde bidrog forberedelsen ikke kun til, at de studerende stolede på deres medstuderendes bidrag, men også til, at de studerende selv turde deltage og stille spørgsmål. Forklaringen synes at være, at fordi alle var forberedt, var der ikke længere risiko for, at dumme spørgsmål blev tolket som manglende engagement eller mangel på forberedelse. De studerende erfarede, at de var med til at blive klogere i fællesskab, og at faren for ansigtstab mindskedes.

At den gensidige afhængighed de studerende imellem blev oplevet positivt, skyldtes især de studerendes oplevelse af underviseren, hendes rammesætning af faget og hendes person. Dels fordi underviseren gennem sin kommunikation og implementering af forberedelsespligten skabte troværdige normer, og dels fordi hun engagerede sig i de studerendes projekter, udover hvad de havde forventet. Underviseren kommunikerede klart sine regler om forberedelsespligten, men implementerede dem så til gengæld med tillid. Således tjekkede hun ikke, om de studerende var forberedt. Der var ingen afkrydsning eller kontrol, hvilket de studerende understregede havde stor betydning.

Det var jo også der, hvor [underviser] meldte klart ud fra starten. Det var ikke, fordi hun startede forelæsningen med at sige: "Hvem har ikke afleveret?" eller sådan noget. Hun gik bare ud fra, at dem, der var mødt op, de havde afleveret, og så var det dét. Ens afleveringer var mest tiltænkt ens feedbackgrupper, så hvis du ikke havde afleveret, så gik det egentlig bare ud over dig selv. (Mandlig studerende)

Analysen viste, at magtrelationerne i undervisningen oplevedes som symmetriske. Underviseren indtog ikke en kontrollant-rolle, og de studerende havde selv ansvaret for deres egen opgave og læringsproces. Der var en fælles forståelse af, at underviseren var den vidende og satte de overordnede rammer, men samtidig var der en oplevelse af, at hun ikke kendte det endelige svar, men støttede de studerende i erkendelser og arbejdet med deres individuelle projekter. 
$J a$, det føltes meget, som om hun rettede ind efter ligesom vores processer, hvor vi var. I stedet for, at vi ligesom skulle rette ind efter et pensum eller semesterplan. Men var vejleder for alle de gange, vi havde hende (...). At det sådan ligesom var med den på. Og det var rigtig rart egentlig, at man følte, hun gjorde det for lige at møde os, hvor vi havde brug for det, og ikke bare, at vi skulle passe ind i en eller anden plan. (Mandlig studerende)

Når underviserens forberedelsespligt blev opfattet som legitim, var det betinget af, at hun selv udviste et stort engagement. Alle de interviewede studerende beskrev underviseren som en, der gjorde noget ekstra. Det kunne være at give meget vejledning eller læse flere sider, end hun var forpligtet til.

Opsummerende kan man om magtrelationerne sige, at de studerende oplevede en gensidig afhængighed og en gensidig respekt, fordi de kunne stole på, at alle var forberedte og bidrog i undervisningen. Dette var i høj grad afgjort af, at underviseren havde kommunikeret sine regler tydeligt. Underviseren udviste en villighed til at lade den asymmetriske magtrelation suspenderes og lade de studerende være eksperter på deres eget felt. Hendes italesatte krav var en invitation til et symmetrisk samarbejde, der tilbød de studerende en rolle som noget andet end elev. De stramme regler var modsvaret af en tillidsfuld implementering og et stort engagement fra underviserens side, som motiverede de studerende til at leve op til forberedelsespligten.

\section{Identitet som studerende}

Det tredje teoretiske parameter var identiteten som studerende. Analysen viste, at de interviewede studerende fik mulighed for at påtage sig en selvstændig rolle og forme faget. Samtidig erkendte de studerende, at de undervejs havde oplevet en frustration ved at blive tvunget til forberedelse, men at dette havde $\varnothing$ get deres udbytte.

De studerende distancerede sig fra elevrollen. Det var vigtigt for dem at være universitetsstuderende. En studerende betegnede 'det rigtige universitet' som et sted, hvor han ikke blot skulle reproducere viden, men hvor han bidrog med ny viden gennem sit eget projekt. En anden studerende beskrev det således:

Så det føltes lidt mere, som om vi var en del af faget og ikke bare sådan passive deltagere $i$ en forelæsning, men nærmere at vi sådan formede faget sammen. Det hjalp faktisk rimelig meget. (Mandlig studerende)

De studerende beskrev samstemmende, hvordan det, at de arbejdede selvstændigt med deres egne projekter, styrkede følelsen af studiekompetence, og det til trods for, at der var en stram styring af processen fra underviserens side. Styringen blev imidlertid oplevet som modsætning til at blive 'overladt til sig selv', hvilket flere studerende beskrev som normalen i deres venners bachelorforløb.

Undervejs i interviewene reflekterede de studerende over, hvordan de havde oplevet at blive tvunget til at forberede sig undervejs i semesteret. En af de studerende forklarede det således:

I starten følte jeg, at jeg var nødt til at være med. Altså, for ikke at komme bagud i opgaven. Fordi alle andre blev tvunget til at lave noget, og hvis jeg så ikke lavede noget, så skulle jeg bare lave det hjemme. Det var i starten af det. Men så efter nogle gange, så 
havde man allerede set, at det egentlig havde hjulpet en videre, ikke? Altså, det var ligesom at komme ned og træne i fitness. Man gider ikke i øjeblikket, men man kan altid føle det bagefter. Så allerede det der med at have gjort det et par gange, så vidste man godt, altså, jeg har den her følelse, og den kan jeg nå frem til. Altså, det er en måde at komme sådan videre. (Mandlig studerende)

De studerende havde oplevet, at kravene havde tvunget dem til at arbejde hårdt fra begyndelsen med et emne og med en metode, de ikke følte sig hjemme i. Flere studerende beskrev, hvordan det var frustrerende eller irriterende at være tvunget til at producere et skriftligt produkt, inden de havde styr på materialet. I den efterfølgende refleksion, som fandt sted i interviewet, sagde de dog alle, at de var glade for processen, fordi de havde fået løbende feedback på deres arbejde. Denne feedback skabte kontinuerlige bed $\varnothing$ mmelser af eget og andres arbejde. Hvad der blev tydeligt især for en af de studerende var, at han blev mere bevidst om kvalitetskriterierne i faget - en færdighed, han var overbevist om, at han ville værdsætte i et kommende arbejde.

Sådan at det ikke bliver sådan, at når man skal komme med en vurdering derude, når man arbejder et eller andet sted, at det ikke bliver sådan: "Okay, min lærer ville ha' sagt at", eller: "Min underviser ville have sagt", men mere at det bliver sådan: "Min vurdering er". Man får den der selvstændige stemme. (Mandlig studerende)

De studerende oplevede, at de i dette undervisningsforløb fik mulighed for at påtage sig en rolle som selvstændig studerende. Dette ikke på trods af rammerne, men i kraft af den kontinuerlige, forpligtende kontakt med både underviser og medstuderende.

\section{Sammenfatning}

Analysen har vist, at der i dette bachelorseminar blev samskabt en forberedelsespraksis, der var forskellig fra de studerendes sædvanlige forberedelsespraksis. Hvor de interviewede studerende ud fra en generel betragtning afviste forberedelsespligten, accepterede de den øjensynligt i det undervisningsforl $\varnothing b$, som udgjorde casen. Analysen afdækkede en række af de omstændigheder, under hvilke de studerende accepterede forberedelsespligten (se figur 1), herunder tydeligt italesatte og fagligt begrundede normer for forberedelse, undervisningsformer, som iscenesatte en klar gensidig afhængighed studerende og underviser imellem, forberedelse, som var direkte relateret til de studerendes eget projekt, samt en underviser, som udviste både interesse, engagement og tillid.

\section{Diskussion}

\section{Pligt, krav, frihed og mulighed}

Praksisser består i tavse antagelser og vaner, og disse bliver først synlige i det øjeblik, de italesættes, udfordres eller brydes. De studerende beskrev bruddet med plejer i en lang række aspekter i deres bachelorseminar, hvor de kun kunne møde op til undervisningen, hvis de var forberedt. Dette fænomen har vi valgt at kalde forberedelsespligt. Denne pligt adskiller sig kvalitativt fra det forberedelseskrav, som de studerende oplevede i andre fag. Forberedelsespligten og forberedelseskravet har ligheder, idet de begge udtrykker en norm. I dette tilfælde en norm om, at man som studerende bør forberede sig.

Det, der karakteriserer kravet i de tavse antagelser i den sædvanlige undervisning, er følgende: Kravet var vagt, hvilket vil sige, at forberedelseskravet kun var flygtigt italesat og sjældent be- 
grundet. I det omfang, forberedelseskravet blev begrundet, dækkede kravet over en appel til de studerende om at erkende det gavnlige af forberedelse for deres egen læring. Man kan også sige, at kravet var rituelt, idet de studerende stadig fandt det fuldstændig legitimt ikke at være forberedt. Endelig kan man sige, at kravet dækkede over et ønske eller et ideal snarere end en $n \emptyset d v e n d i g h e d$ og en gensidighed. Med det menes, at det i den typiske undervisning ville være $\emptyset n s k v æ r d i g t$ og gavnligt for den studerende som individ at være forberedt, uden at den enkeltes forberedelse havde nogen betydning for medstuderende eller undervisere. Det vil sige, at konventionerne, vanerne og ytringerne på mange måder var inkongruente, idet der ikke var overensstemmelse mellem det, der blev sagt, det, der blev gjort, eller det, der blev sanktioneret.

Praksisteorien understreger betydningen af både rammer og relationer i skabelsen af meningsfuld adfærd i en given kontekst (Reckwitz, 2002), og undervisningen i casen adskilte sig fra den normale undervisning, hvad netop angår rammer og relationer. Hvad angår rammerne, var undervisningen organiseret på en sådan måde, at både underviseren og medstuderende var afhængige af hinandens forberedelse. Hvad angår relationerne, beskrev de studerende en tillidsfuld, forstående og respektfuld relation. Kombinationen af rammer, som nødvendiggør forberedelse, og relationer, som er respektfulde, adskiller pligten og kravet, idet der i pligten ligger en forpligtelse på hinanden snarere end et krav fra underviseren til de studerende. En af de studerende beskrev det som, at de studerende ikke bare havde ansvar for egen læring, men i lige så høj grad havde et ansvar for andres læring, fordi det sænkede det samlede niveau, hvis man mødte uforberedt op. I dette tilfælde var der større kongruens i forholdet mellem ytringer, handlinger og sanktioner.

Pligten står i dette studie i forhold til et andet centralt fænomen, nemlig frihed. Den typiske undervisning var karakteriseret ved en såkaldt negativ frihed, hvilket betyder friheden fra tvang. De studerende var de facto frie til selv at afgøre, om de fandt det hensigtsmæssigt at forberede sig eller ej. I casen havde de studerende ikke en sådan frihed. Til gengæld kan man argumentere for, at de studerende som følge af forberedelsespligten nød en såkaldt positiv frihed, hvilket vil sige en frihed til at gøre noget, de ellers ikke ville kunne have gjort. For eksempel medførte pligten, at de studerende kunne have tillid til, at allevar forberedt, hvilket medførte, at de studerende var frie til at deltage på en måde, som de ikke var vant til. At friheden for deltagelse i den normale undervisning er indskrænket, stemmer overens med resultaterne i et studie af Bager og Herrmann (2013), som viste, at rummet for legitim deltagelse blandt en gruppe bachelorstuderende var meget lille, fordi de studerende netop var bekymrede for at forstyrre undervisningen med såkaldt 'dumme spørgsmål'. Tilbage til casen i dette studie er den afgørende pointe denne: Forberedelsespligten bet $\varnothing \mathrm{d}$ på den ene side, at de studerende ikke længere var frie til at deltage $\mathrm{i}$ undervisningen uden at være forberedt. På den anden side medførte forberedelsespligten en større frihed til at være legitime deltagere i den fælles samtale i undervisningen. Derudover beskrev de studerende, at forberedelsespligten havde tvunget dem til at gå i gang med at skrive, selvom de ikke følte sig helt klar. De beskrev, at processen var 'frustrerende' og 'irriterende'. Det interessante og overraskende ved interviewene er imidlertid, at ordet 'tvang', som sædvanligvis har negative konnotationer, i konteksten blev beskrevet positivt. Tvang blev med et in vivoudtryk forstået som at blive 'skubbet til', og denne 'skubben til' de studerende skabte øjensynligt en række muligheder for deltagelse, som de studerende ellers ikke havde oplevet på deres uddannelse hidtil. 


\section{Den autoritative underviser}

I de studerendes beskrivelse af casen vendte de igen og igen tilbage til underviseren, og der er ingen tvivl om, at underviseren havde en helt central rolle for at skabe de omstændigheder, under hvilke forberedelsespligten blev opfattet som værende være legitim. Spørgsmålet er da, hvad der karakteriserer underviseren og underviserrollen i pågældende case. Tilsyneladende har underviseren succes med at balancere styring af rammerne og samtidig få etableret en tillidsfuld relation, og af interviewene fremgik det klart, at netop relationsarbejdet havde haft betydning for de interviewede studerendes motivation og udbytte. Den universitetspædagogiske forskning har kun i mindre omfang beskæftiget sig med relationsarbejde i klasserummet. Det har man til gengæld i gymnasieskolen, hvor forskere som fx Wubells, Opdenakker og Brok (2012) har påvist, at kombinationen mellem $h \varnothing j$ styring (af rammerne) og positiv kontakt (i relationen) er fremmende for motivation og læringsudbytte (Boekaerts, 2010; Cornelius-White, 2007). Kombinationen af høj styring og positiv kontakt betegnes en autoritativ underviserrolle. Vi har i dette studie interviewet et mindre antal studerende i en afgrænset kontekst. Resultaterne synes at være på linje med resultaterne fra gymnasieskolen: at en autoritativ underviserrolle har positiv betydning for studerendes motivation. Flere studier kunne med fordel unders $\varnothing$ ge sammenhængen mellem underviserrolle, relationsarbejde og studerendes motivation i universitetskonteksten.

\section{Identiteten som universitetsstuderende}

Af analysen fremgik tydeligt, at de studerende havde dannet sig en identitet som universitetsstuderende, hvori de distancerede sig fra rollen som gymnasieelever. Tilsvarende tydeligt fremgik det, at de studerende afviste forberedelsespligten på et generelt plan, fordi en sådan ordning mindede dem om værdierne og identiteten fra gymnasiet. At de accepterede forberedelsespligten $\mathrm{i}$ selve casen skyldtes derimod, at pligten her var implementeret på en måde, som ikke stod $\mathrm{i}$ kontrast til identiteten som universitetsstuderende. En vigtig indsigt fra dette studie er således, at forberedelsespligten kun kan opfattes som legitim i det omfang, den er kongruent med de studerendes opfattelse af sig selv som studerende på et universitet.

I den forbindelse meldersig spørgsmålet, hvordan begrebet om en forberedelsespligt forholder sig til et af universitetets bærende værdier, nemlig selvstændighed (Stephens, Fryberg, Markus, Johnson, \& Covarrubias, 2012). Når pligten til at forberede sig ikke blev oplevet som en modsætning til identiteten som selvstændig universitetsstuderende, var det muligvis betinget af, at forberedelsespligten blot var ét element i organiseringen af undervisningen. Pligten til forberedelsen blev nemlig komplementeret af selvstændige valg på en række andre punkter. Fx valgte de studerende selvstændigt det faglige indhold i deres bachelorprojekter. De studerende traf selv beslutningen, om de havde behov for at deltage $\mathrm{i}$ undervisningen og modtage vejledning og feedback, eller om de havde behov for at blive væk for at skrive på opgaven i stedet. Ud over forberedelsespligten tilbød undervisningsforløbet de studerende ligeledes roller som ligeværdige i en faglig samtale, hvor deres vurderinger af eget arbejde blev respekteret. De studerende beskrev endda, hvordan de i netop dette undervisningsforløb oplevede at være på 'det rigtige universitet', og at de, sammen med underviseren, 'formede faget', hvilket blandt andet vil sige, at de i højere grad tog ejerskab; ikke bare for deres eget projekt, men også for de medstuderendes arbejdsprocesser. Analysen antyder således, at forberedelsespligten kan have været medvirkende til at styrke de studerendes faglige integration såvel som deres mestring af det faglige indhold (Tinto, 1975; Ulriksen, 2014, p. 247). Alt dette taget i betragtning peger analysen på, at en indfø- 
relse af forberedelsespligt ikke nødvendigvis står i modsætning til de studerendes selvstændighed og identitet som universitetsstuderende, men at forberedelsespligten tværtimod og under de givne omstændigheder kan have potentiale til ligefrem at $\varnothing$ ge følelsen af selvstændighed hos de studerende.

\section{Styrker, svagheder og forslag til videre forskning}

I dette studie har vi beskrevet og analyseret en forberedelsespraksis i forbindelse med et bachelorseminar på en humanistisk uddannelse. Bachelorseminaret er givetvis en særlig undervisningskontekst, fordi den for det første opleves som central og særlig vigtig for de studerende, og for det andet fordi der er en meget stærk sammenhæng mellem undervisningsaktiviteter og bedømmelse.

Dette har nogle konsekvenser for rækkevidden af studiets konklusioner. Styrken ved casestudiet er, at det tillader os at undersøge empiriske fænomener i deres naturlige kontekst (Yin, 2012), og netop situeretheden er helt afgørende, når man søger at afdække en praksis (Gherardi, 2012, p. 7). Fordi forberedelsen var skriftlig og understøttede opgaveskrivningen, var der en stærk sammenhæng mellem aktiviteter og bedømmelse, der alt andet lige må gøre det mere meningsfuldt for studerende at engagere sig i aktiviteterne. Dette vil ikke nødvendigvis gælde i alle fag, og der er en reel risiko for, at en indført pligt uden samme meningsfuldhed vil blive opfattet som formynderisk. Det vil sige, at det, at studiet er forankret i en helt bestemt kontekst, kan siges at udgøre en udfordring for resultaternes generaliserbarhed. På den anden side kan undervisere i andre kontekster stadig prøve at skabe en stærk, meningsfuld sammenhæng mellem forberedelse, aktiviteter $\mathrm{i}$ undervisningen og bedømmelse inden for de rammer, som er givet.

Dette studie undersøger et brud med den sædvanlige forberedelsespraksis og giver således anledning til at undersøge 'plejer', og hvordan det givne teaching and learning regime udfordres og fortolkes i en særlig undervisningskontekst. Studiet kan imidlertid kun i meget begrænset omfang blotlægge praksissernes interne forbundethed og konsekvensen af forberedelsespligten for de studerendes studieadfærd generelt. Studiet her tillader ikke at undersøge, om denne forberedelsespraksis har konsekvenser for de studerendes andre fag, deres fritidsjob, eller deres fremtidige studiestrategier. Derfor kalder studiet på flere casestudier, som vil tillade en begyndende forståelse af universitetsstuderendes forberedelsespraksisser, for på sigt at kunne udvikle en egentlig teoretisk model.

\section{Konklusion}

Med udgangspunkt $\mathrm{i}$ et bachelorseminar som case og under inddragelse af praksisteori undersøgte vi først, om studerende accepterer en forberedelsespligt, for dernæst at unders $\varnothing$ ge, hvad der afg $\varnothing$, om studerende accepterer eller ikke accepterer pligten til at forberede sig. Vi fandt, at de studerende generelt var imod en forberedelsespligt, men at en forberedelsespligt under givne omstændigheder kunne accepteres; fx en klar og begrundet rammesætning af de studerendes forberedelse, et gensidigt og respektfuldt forhold underviser og studerende imellem samt en meningsfuld sammenhæng mellem de opgaver, de studerende havde pligt til at aflevere, og den måde, hvorpå både undervisning og de studerendes eget projekt var tilrettelagt. Resultaterne bidrager således med ny viden om danske studerendes forberedelsespraksisser, som hidtil kun har været unders $\varnothing \mathrm{gt}$ i kvantitative unders $\varnothing$ gelser, hvori det ikke har været muligt at tage højde for den kontekst, som en forberedelsespraksis altid vil være indlejret i. Artiklen bidrager også 
med den indsigt, at forberedelse handler om meget andet end antallet af timers ugentlig forberedelse, men at forberedelse udgør en praksis, som vanskeligt kan studeres uafhængigt af rammer, relationer og implicitte normer. For undervisere på universitetet er de vigtigste indsigter disse: At det er muligt at påvirke de studerendes forberedelsespraksis. At studerende under visse omstændigheder accepterer pligten til at forberede sig. Og endelig at forberedelsespligten ikke nødvendigvis er en begrænsning af den enkelte studerendes frihed og selvstændighed, men at pligten under de givne omstændigheder kan gøre det muligt for studerende at involvere sig mere i undervisningen og i det faglige fællesskab.

Kim J. Herrmann er lektor på Center for Undervisning og Læring. Hans interesseområde er blandt andet studerendes læringsstrategier, samspillet mellem undervisere og studerende, samt kvantitative metoders anvendelse i uddannelsesforskningen. Kim er desuden ansvarshavende redaktør for Dansk Universitetspædagogisk Tidsskrift og medforfatter til bogen 'Effektiv holdundervisning - en håndbog for nye undervisere på universitetsniveau'.

Anna Bager-Elsborg er postdoc ved Center for Undervisning og Læring og beskæftiger sig med learning analytics og eksamen. Derudover forsker hun i betydningen af fagdisciplin og kontekst for undervisningspraksisser på universitetet. Sideløbende har hun været medansvarlig for studiemiljøundersøgelserne ved Aarhus Universitet i årene 2007-2017. Hun er medforfatter til bogen 'Effektiv holdundervisning - en håndbog for nye undervisere på universitetsniveau'.

\section{Litteratur}

Bager, A. J., \& Herrmann, K. J. (2013). "Du skal ikke stikke næsen for langt frem": Et studie af normer for deltagelse og forberedelse blandt førsteårsstuderende. Dansk Universitetspædagogisk Tidsskrift, 8(15), 36-46.

Barbour, R., \& Kitzinger, J. (1998). Developing focus group research: politics, theory and practice. London: Sage Publications Ltd.

Boekaerts, M. (2010). The crucial role of motivation and emotion in classroom learning. In $\mathrm{H}$. Dumont, D. Istance, \& F. Benavides (Eds.), The nature of learning: Using research to inspire practice (pp. 91-111). OECD: Centre for Educational Research and Innovation.

Cornelius-White, J. (2007). Learner-centered teacher-student relationships are effective: A metaanalysis. Review of Educational Research, 77(1), 113-143.

DEA. (2013). Motivation og studieintensitet hos universitetetsstuderende : en spørgeskemaundersøgelse i Danmark, Sverige, Tyskland og England. Retrieved from København: https://www.statsbiblioteket.dk/au/\#/search?query=recordID\%3A\%22sb 6005710\%22

Flick, U. (2014). An introduction to qualitative research. London: Sage Publications Ltd.

Gerring, J. (2008). Case study research: principles and practices. New York: Cambridge University Press.

Gherardi, S. (2012). How to conduct a practice-based study: Problems and methods. Cheltenham: Edward Elgar Publishing Limited. 
Herrmann, K. J., Bager-Elsborg, A., Hansen, I. B., \& Nielsen, R. B. (2015). Mere undervisning, st $\varnothing r-$ re studieintensitet?: en multilevelanalyse af 7.917 studerendes tidsforbrug. Dansk Universitetspædagogisk Tidsskrift(18), 35-50.

Kvalitetsudvalget. (2014). Høje mål: fremragende undervisning i videregående uddannelser: analyserapport. Retrieved from København: http://ufm.dk/uddannelse-og-institutioner/radnaevn-og-udvalg/kvalitetsudvalget/publikationer/samlet rapport web 01-2.pdf

Miles, M. B., \& Huberman, A. M. (1994). Qualitative data analysis: An expanded sourcebook: sage.

Orr, D., Gwosc, C., \& Netz, N. (2011). Social and Economic Conditions of Student Life in Europe. Synopsis of indicators. Final report. Eurostudent IV 2008-2011. Bielefeld: W. Bertelsmann Verlag.

Reckwitz, A. (2002). Toward a theory of social practices: a development in culturalist theorizing. European journal of social theory, 5(2), 243-263.

Stephens, N. M., Fryberg, S. A., Markus, H. R., Johnson, C. S., \& Covarrubias, R. (2012). Unseen disadvantage: how American universities' focus on independence undermines the academic performance of first-generation college students. Journal of personality and social psychology, 102(6), 1178.

Tinto, V. (1975). Dropout from Higher Education: A Theoretical Synthesis of Recent Research. Review of Educational Research, 45(1), 89-125. doi:10.2307/1170024

Trowler, P. (2008). Cultures and change in higher education: Theories and practices. Basingstoke: Palgrave Macmillan.

Trowler, P., \& Cooper, A. (2002). Teaching and learning regimes: Implicit theories and recurrent practices in the enhancement of teaching and learning through educational development programmes. Higher Education Research \& Development, 21(3), 221-240.

Ulriksen, L. (2014). God undervisning på de videregående uddannelser, en forskningsbaseret brugsbog. Frederiksberg: Frydenlund.

Wubbels, T., Opdenakker, M.-C., \& Brok, P. D. (2012). Let's Make Things Better. Interpersonal Relationships in Education: An Overview of Contemporary Research. (pp. 225-249). Rotterdam: SensePublishers.

Yin, R. K. (2012). Applications of Case Study Research. London: SAGE Publications Ltd.

Aarhus Universitet. (2011). Rapport nr. 1: Studiemiljø2011 - Aarhus Universitet. Retrieved from Aarhus: http://www.au.dk/studiemiljo/rapporter/

Aarhus Universitet. (2014). Rapport nr. 1: Studiemiljø 2014 - Aarhus Universitet. Retrieved from Aarhus: http://www.au.dk/studiemiljo/rapporter-2014/. 